\title{
СУЧАСНІ ФОРМИ ПРОВЕДЕННЯ ЛЕКЦІЙ ЗІ СТОХАСТИКИ ДЛЯ СТУДЕНТІВ ЕКОНОМІЧНИХ СПЕЦІАЛЬНОСТЕЙ УНІВЕРСИТЕТІВ
}

Трунова О. В., Тур Г. І. Сучасні форми проведення лекцій зі стохастики для студентів економічних спеціальностей університетів.

У статті розглянуті сучасні навчальні технології, що підвищують ефективність процесу формування стохастичної компетентності студентів економічних спеціальностей університетів. Визначені основні напрямами вдосконалення стохастичної підготовки майбутніх економістів. Наведений розподіл форм та методів активізації процесу навчання стохастики за темами. Сформульовані вимоги до написання електронного конспекту лекцій зі стохастики. Визначені функції робочого зошита на лекційному занятті.

Ключові слова: стохастика, компетентність, майбутні економісти, навчальні технології, мультимедійна лекція, електронний конспект.

Трунова Е.В., Тур А. И. Современные формы проведения лекций по стохастике для студентов экономических специальностей университетов

В статье рассмотрены современные учебные технологии, повышающие эффективность процесса формирования стохастической компетентности студентов экономических специальностей университетов. Определены основные направления совершенствования стохастической подготовки будущих экономистов. Предложено распределение форм и методов активизации процесса обучения стохастике по темам. Сформулированы требования к написанию электронного конспекта лекций по стохастике. Определены функции рабочей тетради на лекционном занятии.

Ключевые слова: стохастика, компетентность, будущие экономисты, учебные технологии, мультимедийная лекция, электронный конспект.

Trunova Ye. V., Tur A. I. Modern forms of lectures on stochastics for students of economics universities.

In the article the modern educational technologies increasing efficiency of formation of stochastic competence of students of economic specialties are considered. The main areas of stochastic training improvement of future economists are determined. The distribution of forms and methods to enhance the stochastics training process on topics is offered. The requirements for writing e-compendium in stochastics are defined. Functions of workbook in lectures are determined.

Key words: stochastics, competence, future economists, educational technology, multimedia lecture, e-compendium.

Сучасне суспільство формує соціальне замовлення економічним вишам на підготовку висококомпетентних бакалаврів, здатних виконувати свої функції відповідно до профілю на рівні світових стандартів, готових до постійного професійного зростання, соціальної та професійної мобільності.

Особливого значення під час підготовки фахівців у сфері економіки набуває оволодіння ймовірнісно-статистичними методами, оскільки будь-яка підприємницька діяльність пов'язана з невизначеністю досягнення кінцевого результату через вплив великого числа випадкових чинників. 
Реалізація компетентнісного підходу передбачає необхідність упровадження в навчальний процес сучасних освітніх технологій, форм і методів навчання, поряд 3 цим спостерігається значне скорочення аудиторних годин на вивчення дисципліни «Теорії ймовірностей і математична статистика» (ТЙ і MC), що, безсумнівно, призводить до необхідності підвищення ефективності навчання в аудиторії.

Питання методики навчання стохастики розглядаються в дослідженнях К. Велскера, Б. Гнєденко, А. Дограшвілі, М. Жалдака, М. Єремєєвої, А. Колмогорова, К. Куриндіної, Д. Маневича, Г. Михаліна, В. Селютіна та ін. Основною умовою досягнення цілей навчання теорії ймовірностей у зазначених роботах постає його прикладна спрямованість. Методику підготовки студентів економічних спеціальностей ВНЗ висвітлено у працях (Н. Ванжі, Г. Дутки, Л. Нічуговської, Г. Пастушок, Л. Паханової, О. Фомкіної та ін.).

Слід зазначити, що навчання стохастики в університетах здійснюється в основному з використанням традиційних форм і методів. Очевидно, що потрібен перегляд традиційних принципів побудови занять і насамперед виникає проблема підвищення ефективності лекцій.

Метою статті $\epsilon$ виявлення шляхів упровадження в лекційний курс ТЙ і МС сучасних освітніх технологій, форм i методів навчання, що сприяють підвищенню ефективності процесу формування стохастичної компетентності студентів економічних спеціальностей університетів.

Лекція в університеті залишається однією з форм представлення нового навчального матеріалу. У сучасних умовах вона розглядається педагогами як застаріла форма роботи. Але це не зовсім так. Термін «лекція», запропонований Л. Бауером, це навчальна технологія, за допомогою якої представник освітнього підприємства, зазвичай викладач, використовуючи певний проміжок часу, усно надає інформацію на певну тему певному колу слухачів. За цих умов створюється навчальна ситуація, де основним завданням кожного учня є отримання інформації. Однак, лекція не повинна зводитися до простої трансляції знань, адже, як відомо, на сорок п’ятій хвилині від ї̈ початку студенти стають зовсім неуважні і забувають інформацію, подану на початку лекції [3].

Сучасна лекція повинна: бути проблемною за змістом і проведенням; бути гнучкою за структурою, даючи можливість лектору вносити корективи в ході заняття, з урахуванням відповідної реакції слухачів, що отримується на основі зворотного зв’язку; проводиться викладачем, що прагне оволодіти ораторським мистецтвом, орієнтованим не на монолог, а на дискусію або діалог зі слухачами; забезпечуватися наочними посібниками (електронний підручник, електронний конспект лекцій), елементами дистанційних технологій, професійними математичними пакетами, що дозволяють лектору оперувати яскравими образами і наочною інформацією, не зупиняючись на тривіальних, або не змістовних і не принципових питаннях процедурного або розрахункового характеру.

Великі можливості для підвищення ефективності лекції надають сучасні інформаційно-комунікаційні технології. Системи мультимедіа забезпечують більшу свободу ілюстрування навчального матеріалу за рахунок застосування різних способів обробки аудіовізуальної інформації. Нині здійснюються спроби впровадження в освітній процес лекцій-презентацій, електронних підручників тощо. Проте впровадження цих форм і методів носить епізодичний, а не системний характер. Повною мірою в навчальному процесі на сьогоднішній день усі можливості сучасної комп’ютерної техніки використовуються не належним чином [1].

ТЙ і МС є особливою освітньою дисципліною в економічному ВНЗ, вона служить фундаментом для вивчення інших дисциплін, зокрема професійного циклу. 3 іншого боку, 
курс стохастики в економічному виші є одним 3 найважчих для засвоєння. Виникнення труднощів при вивченні ТЙ і МС можна пояснити: специфікою стохастики як науки, яка оперує абстрактними поняттями й образами; низьким рівнем стохастичної підготовки першокурсників (начала стохастики вивчаються в шкільному курсі математики); великим обсягом досліджуваного матеріалу і невеликою кількістю аудиторних годин, відведених на його вивчення.

Основними напрямами вдосконалення підготовки майбутніх економістів вважаються: вдосконалення змісту курсу стохастики в економічному ВНЗ; підвищення рівня підготовки абітурієнтів; професійна спрямованість навчання стохастики:

- через змістовний компонент (прикладні задачі міжпредметного характеру, математичне моделювання);

- методичний компонент (проблемне, контекстне навчання, самостійна дослідницька діяльність, поєднання колективних та індивідуальних форм навчання);

- мотиваційно-психологічний компонент;

- розв’язання прикладних задач в системі не тільки практичних, але й лабораторних робіт; підготовка до вивчення спеціальних дисциплін засобами стохастики, тобто вивчення необхідної стохастичної бази; застосування інформаційних технологій у процесі навчання стохастики [3].

У процесі викладання навчальної дисципліни ТЙ і МС для активізації навчальнопізнавальної діяльності студентів передбачається застосування таких навчальних технологій, як: проблемні лекції, міні-лекції, мультимедійні лекції і мозкові атаки.

Проблемні лекції спрямовані на розвиток логічного мислення студентів. У ході викладання теоретичного матеріалу лектор пропонує запитання проблемного характеру, залучаючи студентів до самостійного розв'язання відповідної задачі. Чітко і зрозуміло сформульована проблема активізує мислення студентів у пошуках правильної відповіді. Проте лектор не чекає грунтовної відповіді студентів, а поступово сам висвітлює розв’язання відповідної проблеми. Отже, змінюється форма взаємодії учасників освітнього процесу студенти 3 пасивних «одержувачів» інформації, як це часто відбувається в рамках традиційної лекції, перетворюються на «генераторів нових знань», беручи активну участь в обговоренні та дослідженні запропонованого матеріалу, викладач вже не $\epsilon$ просто транслятором знань, його роль - спрямовувати хід міркувань і дослідницьку діяльність студентів [2].

Міні-лекції передбачають викладення навчального матеріалу за короткий проміжок часу й характеризуються значним обсягом інформації, складністю логічних побудов та їх узагальнень. Лекційний матеріал подається в так званому структурно-логічному вигляді, зафіксовані у плані лекції питання викладаються стисло. Більш детальне вивчення матеріалу виноситься на самостійне опрацювання.

Мультимедійна лекція - форма організації навчального процесу, що поєднує традиційну лекцію i мультимедійну презентацію, яка дозволяє одночасно задіяти різноманітні форми подання навчальної інформації (графічна, текстова, аудіовізуальна), об’єднані в єдину структуру, що дозволяє донести їі в максимально наочному вигляді. Мультимедійна лекція $є$ не слайд-фільмом, не є спробою замінити викладача комп’ютером, вона є лекцією повною мірою. За такої форми організації навчального процесу викладач як і раніше залишається головною дійовою особою, крім того, у нього з'являється можливість повною мірою реалізувати свій творчий потенціал, зробити лекцію більш змістовною і 
насиченою різноманітним інформаційним матеріалом. Підготовка мультимедійної лекції вимагає особливого підходу до їі змісту і структури. Основоположне значення при цьому має підбір і підготовка навчального матеріалу. Якщо говорити про курс стохастики для студентів економічних спеціальностей, то серед вимог до навчального матеріалу можна виокремити такі: ретельний відбір навчального матеріалу, визначення найбільш важливого (стохастичної суті досліджуваних економічних явищ і процесів); йдучи від надлишкових математичних викладок, необхідно більше уваги приділяти обговоренню наслідків стохастичних законів, їх практичному застосуванню в повсякденному житті, економіці, спостереженню в природі, тобто курс ТЙ і МС в економічному ВНЗ повинен бути практично-орієнтованим; виходячи з того, що обсяг знань, необхідний для засвоєння студентами, все зростає, а час на його засвоєння скорочується, то навчальний матеріал необхідно ущільнювати; отже, для кращого його сприйняття навчальний матеріал повинен бути дуже добре структурованим.

Добре структурований i візуалізований навчальний матеріал може бути представлений у зручному для одномоментного сприйняття вигляді- модулі, блоки логічно закінчені, пов’язані між собою «порції» навчального матеріалу.

Дидактичні вимоги до мультимедійних лекцій можна сформулювати досить чітко. Вони дозволяють: реалізувати науковий рівень вимог, що пред’являються до вишівських лекцій; стимулювати навчально-пізнавальну діяльність студентів; оптимальним чином візуалізувати навчальний матеріал; забезпечити універсальність виконання і варіативність представлення навчального матеріалу, що відповідає практичним потребам викладача й учнів; раціонально поєднувати різні технології представлення навчального матеріалу: синтез візуального (зокрема, мультимедійного) і вербального; забезпечувати контроль знань.

Мозкова атака як метод розв’язання проблем за дуже короткий проміжок часу передбачає спільне обговорення задачі (в малих групах) i здійснення відбору запропонованих ідей щодо іï розв’язання. За формою такий підхід до активізації процесу навчання можна здійснювати у вигляді змагання.

Практичне втілення навчальних технологій за темами дисципліни ТЙ і МС наведено в табл. 1.

Таблиця 1

Розподіл форм та методів активізації процесу навчання за темами навчальної дисципліни

\begin{tabular}{|c|c|}
\hline Тема & Практичне застосування навчальних технологій \\
\hline Тема 1. Імовірнісні міри & $\begin{array}{l}\text { Мультимедійна проблемна лекція з використанням } \\
\text { мозкової атаки } 3 \text { питання: «Переваги та недоліки } \\
\text { різних підходів до означення ймовірності» }\end{array}$ \\
\hline $\begin{array}{l}\text { Тема 2. Дискретні та неперервні } \\
\text { ВВ і закони їх розподілу }\end{array}$ & $\begin{array}{l}\text { Мультимедійна проблемна лекція «Способи задання } \\
\text { закону розподілу ДВВ». } \\
\text { Мозкова атака } 3 \text { питання: «Як знайти функцію } \\
\text { розподілу ДВВ за відомим законом розподілу?» }\end{array}$ \\
\hline $\begin{array}{l}\text { Тема 3. Числові характеристики } \\
\text { ВВ }\end{array}$ & $\begin{array}{l}\text { Мультимедійна проблемна лекція з використанням } \\
\text { мозкової атаки з питання: 1. «Як обчислити середне } \\
\text { значення ДВВ з нескінченною множиною значень?». } \\
\text { 2. «Чи завжди ВВ має математичне сподівання?» }\end{array}$ \\
\hline $\begin{array}{l}\text { Тема 4. Багатовимірні ВВ та їх } \\
\text { розподіл }\end{array}$ & $\begin{array}{l}\text { Мультимедійна проблемна лекція з використанням } \\
\text { мозкової атаки з питання: «У чому полягає перевага } \\
\text { коефіцієнта кореляції як числової характеристики } \\
\text { системи двох ВВ перед коваріацією?» }\end{array}$ \\
\hline
\end{tabular}




\begin{tabular}{|c|c|}
\hline Тема & Практичне застосування навчальних технологій \\
\hline $\begin{array}{l}\text { Tема 5. Закон великих чисел, } \\
\text { центральна гранична теорема }\end{array}$ & $\begin{array}{l}\text { Мультимедійна проблемна лекція з використанням } \\
\text { мозкової атаки } 3 \text { питання: 1. «Чому правило «трьох } \\
\text { сигм» застосовне до будь-якого закону розподілу?». } \\
\text { 2. «За яких умов нерівність Чебишева перетворюється } \\
\text { на рівність?» }\end{array}$ \\
\hline $\begin{array}{l}\text { Тема } 6 . \text { Основи } \\
\text { статистики }\end{array}$ & $\begin{array}{l}\text { Мультимедійна проблемна лекція «Зв’язок між } \\
\text { теорією ймовірностей і математичною статистикою та } \\
\text { Ïх взаємний вплив» }\end{array}$ \\
\hline $\begin{array}{l}\text { Тема } 7 . \text { Перевірка статистичних } \\
\text { гіпотез і статистичне оцінювання } \\
\text { параметрів }\end{array}$ & $\begin{array}{l}\text { Мультимедійна проблемна лекція «Переваги та } \\
\text { недоліки інтервального оцінювання параметрів } \\
\text { порівняно з точковими оцінками» }\end{array}$ \\
\hline $\begin{array}{l}\text { Тема 8. Статистичнй } \quad \text { аналіз } \\
\text { взаємозв’язків }\end{array}$ & $\begin{array}{l}\text { Мультимедійна лекція-дискусія } 3 \text { питання: «У чому } \\
\text { полягає принципова відмінність кореляційного і } \\
\text { регресійного аналізів у математичній статистиці?» }\end{array}$ \\
\hline $\begin{array}{l}\text { Tема 9. Статистичний аналіз еко- } \\
\text { логічних, економічних } \\
\text { соціальних процесів }\end{array}$ & $\begin{array}{l}\text { Мультимедійна проблемна лекція «Планування } \\
\text { системи освіти і планування кадрів» }\end{array}$ \\
\hline $\begin{array}{lc}\text { Tема } 10 . \quad \text { Імовірнісні } \\
\text { випадкові послідовності }\end{array}$ & $\begin{array}{l}\text { Мультимедійна міні-лекція «Взаємні коваріаційна і } \\
\text { кореляційна функції двох випадкових процесів» }\end{array}$ \\
\hline $\begin{array}{l}\text { Тема 11. } \quad \text { Марківські } \quad \text { процеси, } \\
\text { ланцюги, потоки подій }\end{array}$ & $\begin{array}{l}\text { Мультимедійна проблемна } \\
\text { ланцюги як розція }\end{array}$ \\
\hline $\begin{array}{l}\text { Тема 12. Системи обслуговування } \\
\text { марківського типу }\end{array}$ & $\begin{array}{l}\text { Мультимедійна міні-лекція «Випадковий процес } \\
\text { народження і загибелі» }\end{array}$ \\
\hline
\end{tabular}

На лекції поряд з мультимедійними засобами і живим спілкуванням лектора в аудиторії найбільш ефективно можна використовувати електронний конспект лекції та робочі зошити. Основні вимоги до написання електронного конспекту лекцій: насиченість малюнками, комп’ютерною графікою, відеофрагментами; побудова системи анімації так, щоб спочатку з'являвся текст, потім ілюстрація; загальна кількість слайдів - 45-60; однакові стилі заголовків і підзаголовків, напівжирний шрифт, в межах одного слайда не більше ніж два типи шрифтів; однотонний фон слайда; розташування ілюстративних матеріалів ліворуч візуального поля екрану, текст - праворуч.

3 нашої точки зору, використання робочого зошита на лекційному занятті зі стохастики у виші виконує низку функцій: пропедевтика - попереднє ознайомлення учнів з основними поняттями, визначеннями і теоремами в короткому їх викладі, а також питаннями для повторення. Під час проблемної лекції в робочому зошиті можливо сформулювати питання для обдумування, формулювання і подальшого розв’язання проблеми; синхронне конспектування матеріалу учнями; економія часу на лекційному занятті (особливо коли лекція супроводжується кресленнями, графіками, малюнками тощо); доповнення матеріалу лекції після ії̈ завершення (за матеріалами підручника чи електронного підручника); оперативний поточний контроль матеріалу, вивченого на лекції (у формі невеликого тесту, опитувальника тощо).

У структуру робочого зошита зі стохастики можуть входити такі компоненти: назва лекції; мета лекції, основні проблеми; глосарій; складні ілюстрації, схеми; основний матеріал лекції: теоретичний - для конспектування, практичний - виконання вправ за зразком, що закріплює самостійне виконання завдань; місця для відповідей на поставлені в лекції запитання; доповнення конспекту в роботі з підручником / поля. 
Методика викладу, поруч із загальнодидактичними вимогами, передбачає також низку технологічних новацій: оптимальний вибір послідовності демонстрації слайдів (використовуючи гіперпосилання переходів по них), часу експозиції кожної порції навчального матеріалу, оптимальних моментів для «вмикання». Базуючись на цих положеннях, для проведення мультимедійних лекцій з курсу стохастики в економічному ВНЗ авторами розроблений комплект презентаційних матеріалів в MS Power Point. Презентації розроблені до кожної лекції з усього курсу стохастики.

Мультимедійні лекції 3 використанням описуваного комплекту презентаційних матеріалів проводилися протягом трьох навчальних років зі студентами економічних спеціальностей, що дозволило виявити і сформулювати деякі позитивні моменти.

Використання великої кількості ілюстративного матеріалу, передовсім динамічного ряду, відіграє величезну роль в освоєнні суті досліджуваних стохастичних явищ і процесів, а також принципів їх використання на практиці. Наочність, лаконічність і естетичність висунутого навчального матеріалу, реалізованого за допомогою інформаційних технологій, дозволяють істотно скоротити час на оформлення записів на дошці. При цьому, однак, не варто відмовлятися від використання звичайної або інтерактивної дошки.

Роздруковані слайди презентації (опорні конспекти) полегшують роботу студента 3 подальшого засвоєння навчального матеріалу та підготовку до іспиту. Однак потрібно пам'ятати, що записи в зошиті, зроблені студентом під час лекції, дуже важливі, тому що дозволяють задіяти різні види пам’яті.

Під час проведення мультимедійної лекції можна урізноманітнити форми організації навчальної діяльності - крім уже згадуваних проблемних лекцій та дискусій, можна організувати і дослідницьку діяльність студентів за допомогою спеціальних завдань задля опрацювання окремих найбільш цікавих і важливих питань спостереження і використання стохастичних явищ, процесів у природі й економічній практиці.

Проведення мультимедійних лекцій не вимагає спеціальної підготовки викладача, освоїти методику їх проведення можна досить легко. Проведення навчальних занять на сучасному рівні дозволяє підвищити авторитет викладача, що важливо для повноцінної взаємодії викладача і студентів.

\section{Література}

1. Активные и интерактивные образовательные технологии высшей школе : [учеб. пособие] [Электронный ресурс] / сост. Т. Г. Мухина. - Нижний Новгород: НГАСУ, 2013. 97 с. - Режим доступа : www.nngasu.ru/education/high_education/ education_manual.pdf 2. Реутова Е. А. Применение активных и интерактивных методов обучения в образовательном процессе вуза метод. рекомендации для преподавателей Новосибир. ГАУ [Электронный ресурс] : - Новосибирск : НГАУ, 2012. - Режим доступа : www.nsau.edu.ru/file.

3. Трунова О. В. Особливості лекційного курсу стохастики для студентів економічних спеціальностей / О.В.Трунова // Педагогічні науки: теорія, історія, інноваційні технології: Науковий журнал. - Суми : СумДПУ ім. А. С. Макаренка, 2014. - № 5 (39). - С. 361-376. 